\title{
Qualification of Force Majeure in the Covid-19 Pandemic as a Reason for Cancellation of Contract
}

\author{
Tina Amelia \\ Borobudur University, Indonesia \\ \{tinaamelia3009@gmail.com\}
}

\begin{abstract}
Engagement is a legal relationship that occurs between the parties who have agreed on the matters set forth in the contract that creates an obligation to fulfill the contents of the contract. However, there is a situation where one party is unable to perform its accomplishment due to event occur against its will, known as force majeure. In dealing with Covid-19, Presidential Decree No. 12 of 2020 concerning the Determination of Non-Natural Disaster for the Spread of Corona Virus Disease 2019 (Covid-19) as a National Disaster rise public speculation about whether the Covid-19 pandemic can qualify as force majeure due to the effects of the Covid-19 pandemic disrupting activities in the business sector which resulted in the inability to fulfill accomplishment, thus making the Covid-19 pandemic an excuse to cancel the contract. Research method in this research is juridical-normative legal research. The results of this study that the Covid-19 pandemic cannot be used as a reason for contract cancellation because it must analyzed the force majeure clause states in contract first, and the real conditions to fulfill obligations in the contract. With the Covid-19 pandemic possible to conduct negotiations to postpone, change or cancel the contents of the contract.
\end{abstract}

Keywords: Covid-19 pandemic; force majeure; contract.

\section{Introduction}

Community welfare is a goal to be achieved in the implementation of economic development, where in terms of national economic development it must be carried out based on economic democracy with the principles of togetherness, equitable efficiency, sustainability, environmental insight, independence, and maintaining a balance of progress and national economic unity in order to achieve these goals. As is the case with the objectives of the Indonesian state as stated in the Preamble to the 4th paragraph of The 1945 Constitution of the Republic of Indonesia, namely "... to advance the general welfare, .." For this reason, in terms of realizing a public welfare, the roles of business actors in development are needed. In addition to that, the role of the state in economic development in Indonesia is very important in that in order to realize the welfare of the people in economic development, there must be a role for the state in it as stated in Article 33 paragraph (2) and paragraph (3) of The 1945 Constitution of the Republic of Indonesia.

The economic condition in Indonesia as a developing country, must continue to be addressed in order to create public welfare in accordance with the mandate of the constitution. Because welfare is one of the benchmarks for a country that is said to be 
developed and developing, the better the distribution of the economy in a country, the more prosperous a country is. At the beginning of 2020, the world experienced the Corona Virus Disease 2019 pandemic (abbreviated as Covid-19), where the spread of the Covid-19 Pandemic poses a risk to public health and has even claimed lives for those infected in various parts of the world, including in Indonesian country. The Covid-19 pandemic also significantly disrupted economic activity and had major implications for the economies of most countries around the world, including Indonesia.

The Covid-19 pandemic that hit almost all countries in the world has had a serious impact on the economy of the people, especially in Indonesia. In response to the Covid-19 Pandemic, the President issued Government Regulation No. 21 of 2020 concerning LargeScale Social Restrictions (in bahasa: Pembatasan Sosial Berskala Besar (PSBB)) in the Context of Accelerating the Handling of Corona Virus Disease 2019 (Covid-19), so that on the basis of these regulations, during the Covid-19 Pandemic period required the closure of company operations due to the prohibition of operating during the Limitation period. PSBB which has the potential to disrupt the company's liquidity and lead to bankruptcy that befell the company, which in turn will have an impact on the company's ability to fulfill its achievements in a contract.

A business relationship that is stated in a written contract creates a legal relationship called an agreement between the parties who agree on the matters set out in the contract so that it creates an obligation to carry out the contents of the contract. However, in practice, there is a situation where one party is unable to fulfill its accomplishment to the other party in a contract due to events that occur outside its control, or what is known as force majeure. According to Black's Law Dictionary, force majeure is "an event or effect that can be neither anticipated nor controlled".

According to Subekti, there are 2 (two) types of force majeure, namely absolute and relative force majeure. In absolute force majeure, it is impossible for the parties to exercise their rights and obligations. The reason is due to permanent obstacles, such as natural disasters such as earthquakes, floods, landslides, etc. Whereas in relative force majeure, it is still possible for the parties to exercise their rights and obligations, so the agreement is only limited to being temporarily suspended. The effect of force majeure that is absolute is exemption from fees, losses and interest arising from the agreement, exemption of parties from fulfill its accomplishment and may have an impact on the cancellation of the agreement. Meanwhile, the result of relative force majeure is exemption from fees, losses and interest, but this does not end with the cancellation of the agreement. In its relative nature, exemption is only temporary and during force majeure it prevents the debtor from fulfill its accomplishment [1].

In response to Covid-19, it also coincided with the enactment of Government Regulation No. 21 of 2020 concerning Large-Scale Social Restrictions (PSBB) in the Context of Accelerating the Handling of Corona Virus Disease 2019 (Covid-19), the President of the Republic of Indonesia, Joko Widodo, has issued another legal instrument, namely Presidential Decree No. 11 of 2020 concerning the Determination of the Public Health Emergency of Corona Virus Disease 2019 (Covid-19) and Enactment of Government Regulation in Lieu of Law No. 1 of 2020 concerning State Financial Policy and Financial System Stability for Handling the Corona Virus Disease 2019 (Covid-19) Pandemic and/or 
in the Context of Facing Threats that Endanger the National Economy and/or Financial System Stability.

In addition to these regulations, Presidential Decree No.12 of 2020 concerning the Determination of the Non-Natural Disaster for the Spread of Corona Virus Disease 2019 (Covid-19) As a National Disaster, with the issuance of the Presidential Decree, caused public speculation about whether this Covid-19 pandemic can qualify as force majeure due to the effects of the Covid-19 pandemic disrupting activities in the business sector which results in the inability to fulfill its accomplishment because it is obstructed by a compelling situation, thus making the Covid-19 pandemic a basis for canceling contract.

The research method used in this research is juridical-normative legal research, with library material that includes primary legal materials, namely The 1945 Constitution of the Republic of Indonesia, Indonesian Civil Code, and Presidential Decree No.12 of 2020 concerning Determination of the Non-Natural Disaster for the Spread of Corona Virus Disease 2019 (Covid-19) As a National Disaster, then secondary legal materials which include previous legal research, legal books, scientific journals, and other legal materials, then finally the tertiary legal materials includes the Big Indonesian Dictionary (in bahasa: Kamus Besar Bahasa Indonesia (KBBI)), Black's Law Dictionary, and encyclopedias.

This study has 2 (two) problem formulations, namely first:

1) How is the Analysis of the Elements of Force Majeure in General?

2) Can Covid-19 qualify as a force majeure so that it can become the basis for the cancellation of contract unilaterally?

\section{Analysis and Discussion}

\subsection{Analysis of the Elements of Force Majeure in General}

An agreement is a very important aspect in business activities where a business relationship is certainly based on an agreement or contract. The term contract in English is called contract and is a translation of the Dutch word "overenkomst" which comes from the root word overeenkomen which means agree or agree. So "overenkomst" contains an agreement in accordance with the consensualism principle adopted by Indonesian Civil Code. Therefore, the term translated must be able to reflect the principle of agreement [2].

A contract is an agreement made by the parties and is usually in written form, where an agreement gives birth to legal consequences in the form of rights and obligations, where something that is a right for one party to the agreement will be an obligation for the other party. The parties that agree on the things that are agreed upon, are obliged to obey and implement them, so that the agreement creates a legal relationship called an agreement.

The meaning of agreement is regulated in article 1313 of Indonesian Civil Code, namely: "An agreement is an act whereby one or more people bind themselves to one or more other people." According to Article 1320 of Indonesian Civil Code, the agreement must meet 4 (four) conditions so that the agreement can be said to be valid, including: 
1) Agree on those who commit themselves.

2) The ability to make an engagement.

3) There is a certain thing.

4) A cause that is lawful.

Making an agreement is to have a legal relationship and those who can carry out a legal relationship are supporters of rights and obligations, both persons or legal entities, which must meet certain conditions. If the contractor is a legal entity, the legal entity must fulfill the requirements as a legal entity [3]. Wirjono Prodjodikoro in his book "Principles of Agreement Law" argues that an agreement is a legal relationship regarding property between two parties, in which a party promises or is deemed to promise to do something or not to do something, while the other party has the right to demand the implementation of that promise [4].

The agreement is born with an agreement of at least 2 (two) related parties, where the agreement is based on the partie's freedom of contract [5]. A binding contract must be executed in good faith by the parties [6]. The provisions of the agreement law used in Indonesia are the provisions in Book III of Indonesian Civil Code concerning Engagement, where one of the main principles underlying the contract law is the principle of freedom of contract [7].

The definition of this principle is seen in Article 1338 of Indonesian Civil Code which reads "All agreements made legally are valid as law for those who make them". This is in line with the system adopted by the agreement, namely the open system, in which the law of the agreement provides the widest possible freedom to the parties to determine what the contents of the agreement are made as long as it does not violate the law, public order and morality. This article shows that the agreement agreed upon by the two parties concerned binds both parties or parties concerned with the aim that the interests of the other party are protected because when the agreement is made based on the agreement of the two parties concerned, then the cancellation must also be done based on agreement both sides [8].

In the discipline of covenant law, one very important principle is recognized. The principle in question is the principle of strength to bind the agreement (Pacta Sunt Servanda). This principle means that the parties making the agreement must carry out the agreement. In this principle, the agreement of the parties is binding as befits a law for the parties making it [9].

In practice, a contract does not always fulfill its purpose and purpose where one of the parties may not fulfill its obligations as agreed from the moment the agreement is made so that it may result in default. Default can occur either on purpose or unintentionally, because one party is not able to fulfill its accomplishment or because they are forced to not be able to fulfill its accomplishment. Default can be in the form of: complete failure to perform, imperfect performance, late accomplishment and doing what is in the agreement it is prohibited to do so [10].

Default in an engagement can be caused by two things, namely:

1) Due to debtor's fault, whether on purpose or negligence.

2) There is a state of force or beyond the ability of the debtor (overmacht/force majeure). 
Prof. R. Subekti argues that the force majeure is a situation where the debtor shows that the agreement is not carried out due to things that are completely unexpected, and where he cannot do anything about circumstances or events that arise unexpectedly [11]. According to Munir Fuady, the term of force majeure is a condition that prevents a person from fulfill its accomplishment due to unexpected circumstances at the time the agreement is made, the situation/event cannot be accounted for to the creditor because the debtor's condition is not in a bad faith state [12].

Based on its nature, force majeure can be divided into 2 (two), namely absolute force majeure and relative force majeure. Absolute force majeure is a condition where the debtor is completely unable to fulfill its accomplishment to the creditor, one of which is when the object of the object is destroyed due to natural disasters, while relative force majeure is a condition that causes the debtor to still be able to fulfill its achievement, but the fulfillment of the accomplishment must be done by make an unbalanced large sacrifice or force beyond human capacity or are likely to be subjected to great harm [13].

Regulations regarding force majeure conditions can be seen in Article 1244 and 1245 of Indonesian Civil Code, which confirms that a situation where what is promised is not carried out is due to things that are completely unpredictable and the debtor cannot do anything about the situation or event. which arose beyond these expectations [14]. In addition, force majeure is also regulated in Article 1444 and 1445 of Indonesian Civil Code, in which these articles do not explicitly state a condition that qualifies as force majeure, but through these articles the elements of a condition that can be identified can be identified. is said to be force majeure. These articles can be described as follows:

a) Article 1244 of Indonesian Civil Code

"If there is a reason for that, the debtor must be punished with compensation for costs, losses and interest if he cannot prove that the agreement was not carried out or not at the right time due to an unforeseen thing, and could not be held accountable to him. that is, if bad faith is not on his side."

b) Article 1245 of Indonesian Civil Code

"It is not the cost of loss and interest, it must be replaced, especially because of coercive circumstances or because of an accidental incident the debtor is unable to give or do something that is required, or because the same things have committed an illegal act."

c) Article 1444 of Indonesian Civil Code

1) If certain goods which are the material of the agreement, are destroyed, can no longer be traded, or are lost, in such a way that it is not known at all whether the goods are still there, then terminate the engagement, as long as the goods are destroyed or lost beyond the fault of the debtor, and he neglected to hand it over.

2) Even if the debtor is negligent in handing over something while he has not been responsible for unforeseen events, the contract is forfeited if the goods will be destroyed equally in the hands of the debtor, if it has been handed over to him.

3) The debtor is obliged to prove the unforeseen event that was brought forward. 
4) In no way whatsoever an item, which has been stolen, destroyed or lost, the loss of this item never frees the person who stole the goods from his obligation to change the price.

d) Article 1445 of Indonesian Civil Code

"If the goods owed, apart from the fault of the debtor, are destroyed, can no longer be traded, or are lost, then the person in debt, if he has rights or claims for compensation regarding said goods, is obliged to provide rights and demands. it to the person who credited it to him."

Based on the articles of Indonesian Civil Code above, the elements of a compelling situation may include: unexpected events; cannot be accounted for to the debtor; there is no bad faith from the debtor; there is an accidental situation by the debtor; this condition prevents the debtor from performing; if the accomplishment is carried out, it will be subject to prohibition from circumstances other than the debtor's fault; the debtor does not fail to perform (handing over the goods); this incident cannot be avoided by anyone (both debtors and other parties); and the debtor is not proven to have made a mistake or negligence.

Due to the wide possibilities of circumstances or situations that can qualify as a force majeure, parties to obtain legal certainty should include a clause with a list of events that can become a force majeure in their agreement, and they should regulate the consequences of a force majeure event, for example whether to delay agreement or can be used as a condition for the cancellation of an agreement.

\subsection{Qualification of Covid-19 as a force majeure so that it can become the basis for the cancellation of contract unilaterally}

The activities of the business world, both national and international, have received a huge impact due to the spread of the Covid-19 Virus which has made a number of countries and governments take policies that have legal implications, such as the Large-Scale Social Restrictions (PSBB) policies, lockdown and/or social distancing that disrupt business entities so that it is likely that many contracts, agreements, business transactions or activities are delayed due to the Covid-19 Pandemic.

In business, failure to fulfill the agreement due to the force majeur condition can be justified by law if one of the parties who cannot fulfill the achievements can prove that there are obstacles that cannot be avoided, but related to the Covid-19 Pandemic still needs to be legally analyzed whether it is the Pandemic Covid-19 can be used as an excuse as a force majeure so that one party cannot carry out the contents of the agreement that has been agreed upon.

Force majeure regulation is generally divided into 2 (two) groups, namely force majeure which is determined as a clause that must be included in the contract regarding the substance stipulated in statutory regulations but not related to the contract or agreement regarding the substance regulated in the legislation [15]. In a contract or agreement, the 
existence of a force majeure clause is a common clause contained in it. Force Majeure can be said to be one of the clauses because its position in an agreement is in a main agreement that is not separate as an additional agreement and is related to the main agreement as an accesoir agreement (additional). Judging from the definition of Force Majeure itself, it is a condition where the debtor is unable to perform his performance to the creditor after the approval is made, where the debtor cannot be blamed and cannot suspect an incident that occurs outside his/her power.

In response to Covid-19, the President of the Republic of Indonesia, Joko Widodo, has stipulated Presidential Decree No.12 of 2020 concerning the Determination of Non-Natural Disasters for the Spread of Corona Virus Disease 2019 (Covid-19) where in Point One the regulation states that non-natural disasters that occur caused by the spread of Covid-19 as a national disaster. Non-natural disasters caused by Covid-19 have had an impact on increasing the number of victims, property losses, expanding the coverage of areas affected by disasters, and having implications for broad social and economic aspects in Indonesia. This regulation has resulted in public speculation, especially by business actors, that this regulation can be used as a legal basis for force majeure.

Regarding whether the Covid-19 Pandemic can qualify as a force majeure, it is necessary to conduct a thorough legal analysis first. Based on Article 1 paragraph (3) of Law Number 24 of 2007 concerning Disaster Management, it is stated that: "Non-natural disasters are disasters caused by non-natural events or series of events, which include technological failure, modernization failure, epidemics, and disease outbreaks." There are different definitions between an epidemic, an epidemic and a pandemic, where an outbreak is a disease that is spread but can still be anticipated, an epidemic is a disease that is spread in large numbers spread over a geographic area, and a pandemic is a disease with its spread to the international level. Covid-19 qualifies as a pandemic based on a statement issued by the World Health Organization which in March 2020 declared Covid-19 a global pandemic [16]. Based on these matters, epidemics and disease outbreaks can qualify as non-natural disasters caused by a series of non-natural events. Law Number 24 of 2007 concerning Disaster Management is the basis that the Covid-19 Pandemic can qualify as a non-natural disaster which has also been strengthened by Presidential Decree No.12 of 2020 concerning the Determination of Non-Natural Disasters for the Spread of Corona Virus Disease 2019 (Covid-19).

However, even though the Covid-19 pandemic which is a global pandemic has caused many business actors to be unable to carry out their obligations, with the Presidential Decree Number 12 of 2020 concerning the Determination of Non-Natural Disasters for the Spread of Corona Virus Disease 2019 (Covid-19) as a National Disaster, Covid-19 cannot be immediately used as a legal basis for force majeure to be able to cancel an existing contract. The contract must continue to be executed in accordance with its contents as based on Article 1338 of Indonesian Civil Code which states that every agreement made legally applies as a law for those who make it.

The Covid-19 pandemic as a non-natural disaster cannot be immediately used as an excuse for cancellation of contracts for reasons of force majeure because whether or not the Covid-19 Pandemic can qualify as a force majeure depends on the contents of the clauses in each contract that has been made, It needs to be analyzed comprehensively that whether in 
the clause in the contract there is an agreement that in the event that qualifies as force majeure, then one of the parties will be given the dispensation not to carry out its obligations.

In an agreement, it is first important to note that whether the force majeure clause is determined in the agreement made, and it is necessary to ascertain what conditions are regulated in the force majeure provisions in order to provide legal certainty to prove the force majeure element as something that is unexpected which causes one of the parties unable to carry out its obligations and the element of a matter cannot be blamed on him.

The Covid-19 pandemic can qualify as a force majeure depending on the definition of a condition that can be qualified as a force majeure that has been included in the contract. As long as one of the parties affected by the Covid-19 Pandemic is able to prove that force conditions have been met, then he can claim that the Covid-19 Pandemic is a force majeure. Based on the explanation of the characteristics of force majeure, the Covid-19 national disaster is a temporary or relative force majeure in which the Covid-19 Pandemic only delays the fulfillment of one party's obligations to the other and does not completely eliminate the obligations of each party.

Based on the analysis above, and to respond to the Covid-19 Pandemic in a business contract relationship, it is possible for the parties to conduct renegotiate to postpone, change or cancel the contents of the contract based on the agreement of the parties by sticking to the applicable Prevailing Laws and implemented with good faith of each party.

\section{Conclusion}

Based on the discussions that have been previously described, the conclusions that can be conveyed are as follows:

1) Regulations regarding the elements of a condition that qualify as force majeure can refer to Article 1244, 1245, 1444 and 1445 of Indonesian Civil Code. Due to the wide range of circumstances or situations that can qualify as a force majeure, the parties should include a clause in the agreement made with a list of events that can qualify as force majeure, as well as their legal consequences, in order to guarantee legal certainty.

2) With the stipulation of Presidential Decree Number 12 of 2020 concerning the Determination of Non-Natural Disaster for the Spread of Corona Virus Disease 2019 (Covid-19) As a National Disaster it cannot be immediately used as a legal basis for force majeure to be able to cancel existing contracts and whether or not The Covid-19 pandemic qualifies as a force majeure depending on the contents of the clauses in each contract that has been made. It is possible for the parties to conduct renegotiate to postpone, change or cancel the contents of the contract based on the agreement of the parties by sticking to the applicable Prevailing Laws and implemented with good faith of each party. 


\section{References}

[1] R. Subekti: Hukum Perjanjian. PT Intermasa, Jakarta. pp. 54.

[2] Moc. Chidir Ali, H. Achmad Samsudin dan Mashudi: 1993, Pengertian-Pengertian Elementer Hukum Perjanjian Perdata, Mandar Maju, Bandung. pp. 21 (1993).

[3] Handri Raharjo: Hukum Perusahaan, Pustaka Yustisia Yogyakarta. pp. 25 (2009).

[4] Wirjono Prodjodikoro: Azas-Azas Hukum Perjanjian, Mandar Maju, Bandung. pp. 4 (2000).

[5] Christiana Tri Budhayati: Asas Kebebasan Berkontrak Dalam Hukum Perjanjian Indonesia, Jurnal Widya Sari, Vol. X, No. 3, Januari 2009. pp. 232 (2009).

[6] M. Muhtarom: "Asas-Asas Hukum Perjanjian Suatu Landasan Dalam Pembuatan Kontrak", Jurnal Suhuf, Vol. 26, No. 1, Mei 2014. pp. 50 (2014).

[7] Lina Jamilah, Asas Kebebasan Berkontrak Dalam Perjanjian Standar Baku, Jurnal Ilmu Hukum Syariah Hukum, Vol. XIII, No. 1, Maret-Agustus 2012, pp. 228 (2012).

[8] Ahmadi Miru: Hukum Kontrak Perancangan Kontrak, RajaGrafindo Persada, Jakarta. pp. 79 (2008).

[9] Ridwan Khairandy: Iktikad Baik Dalam Kebebasan Berkontrak, UI Press, Jakarta. pp. 28 (2004).

[10] Ahmadi Miru: Hukum Kontrak dan Perancangan Kontrak, Rajawali Pers. Jakarta. pp. 74 (2011).

[11] R. Subekti: Hukum Perjanjian. PT Intermasa, Jakarta. pp. 55 (2008).

[12] Munir Fuady: Hukum Kontrak (dari Sudut Pandang Hukum Bisnis), PT Citra Aditya Bakti, Bandung. pp. 113 (2007).

[13] Salim H.S.: Hukum Kontrak Teori \& Teknik Penyusunan Kontrak, Sinar Grafika, Jakarta. pp. 102 (2019).

[14] Rahmat S.S. Soemadipradja: Penjelasan Hukum Tentang Keadaan Memaksa (Syaratsyarat pembatalan perjanjian yang disebabkan keadaan memaksa/force majeure, PT. Gramedia, Jakarta. pp. 72 (2010).

[15] Rahmat S.S. Soemadipraja: Penjelasan Hukum Tentang Keadaan Memaksa (Syaratsyarat Pembatalan Perjanjian Yang Disebabkan Keadaan Memaksa/Force Majeure), Gramedia, Jakarta. pp. 71 (2010).

[16] Gloria Setyvani Putri: "WHO Resmi Sebut Virus Corona Covid-19 sebagai Pandemi Global", https://www.kompas.com/sains/read/2020/03/12/083129823/who-resmi-sebutvirus-corona-covid-19-sebagai-pandemi-global?page=all, accessed on 17 February at 18.30 WIB. 